
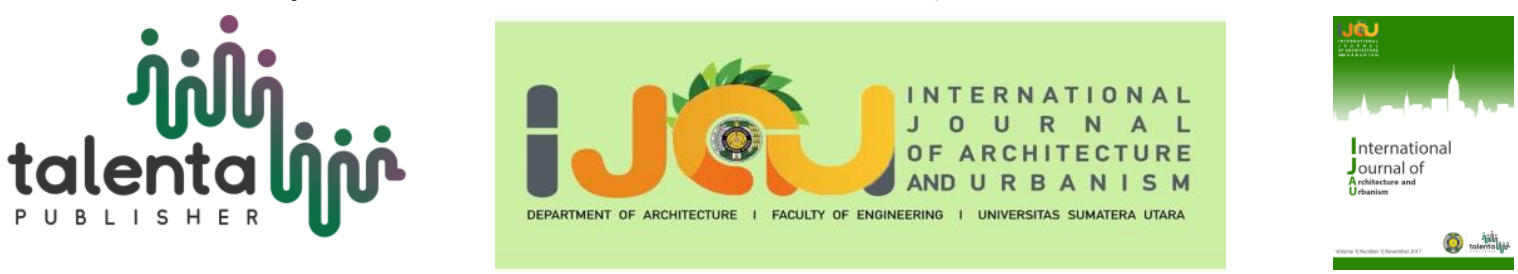

\title{
Growth Pattern of Pancur Batu Sub District in Kabupaten Deli Serdang Base on Ecological approach
}

\author{
Farhan Bagas $F^{1^{*}}$ \\ ${ }^{1}$ Karaka Architect, Medan, Indonesia
}

\begin{abstract}
Pancur Batu is one of the sub-districts in Deli Serdang. Before 1945 Pancur Batu was called Sinuan Bungan with the capital city of Arhnemia, but in 1952 it changed administratively under Deli Serdang district. An Area's growth pattern of an area is directly proportional to the development of the socio-cultural, economic, and political elements. Using Kecamatan Pancur Batu, Kabupaten Deli Serdang as a case study, this paper systematically introduces an ecological approach methodology. The growth pattern of the Pancur Batu sub-district is the result of history and through a long process. The Pancur Batu sub-district environmental development is influenced by several factors, such as politics, economy, socio-culture, and ecological carrying capacity. These factors have a significant influence between the environment and humans.
\end{abstract}

Keyword: ecological, growth pattern, Pancur Batu

Received date month year. | Revised 12 October 2020 | Accepted 15 November 2020

\section{Introduction}

Regions will always grow and develop in line with the development of socio-cultural life, the economy and politics that the background. Urban development is the result works of the construction of human thought both in terms of adaptation to the environment and adjustment. Culture is one of the factors that cause images from images areas are subject to change. Regions people with a certain background from traditional life patterns to modern affect changes in regional formation. Cultural stability factor society in maintaining the penetration of outside culture (influence of acculturation and assimilation [1]. With a population of 84.919 people [2], Pancur Batu is one of the sub-districts located in Deli Serdang Regency. During the Dutch era, the Pancur Batu sub-district was known as Sinuan Bungan with the capital city of Arhnemia. However, in 1952 the Governor of North Sumatra, Abdul Hakim, changed the Deli Serdang TK's civil service.II district administratively, divided into 6 (six) kawedanans consisting of 30 sub-districts, the Pancur Batu district.

\footnotetext{
*Corresponding author at: Karaka Architect, JI Sei Blutu No. 58, Medan Indonesia

E-mail address: farhanbagas16@gmail.com
} 
The residents who live in Pancur Batu District consist of various tribes in 30 June 2016, including:[5]

Table 1 List of Tribes in Pancur Batu

\begin{tabular}{ll}
\hline Karo & $7843 \mathrm{KK}$ \\
\hline Java & $6.449 \mathrm{KK}$ \\
\hline Minang & $2.260 \mathrm{KK}$ \\
\hline Chiness & $174 \mathrm{KK}$ \\
\hline North Tapanuli & $3.783 \mathrm{KK}$ \\
\hline South Tapanuli & $2.483 \mathrm{KK}$ \\
\hline Nias & $454 \mathrm{KK}$ \\
\hline Tamil & $211 \mathrm{KK}$ \\
\hline Jumlah & $23.648 \mathrm{KK}$
\end{tabular}

In 1974 and the growth of the city of Medan, several villages in the Pancur Batu sub-district were taken over to become the Medan city area, namely, Lau Cih Village, Namo Gajah Village, Simalingkar-B Village, Kemenangan Tani Village, and a new village, Pancur Batu District. has an area of 11,147.35 [4] and have ethnic diversity (Table 1).

The term ecology has the meaning of studying the relationship between organisms and their environment [3]. In its development, ecology is divided into three directions (focus) [6] First; it focuses on analyzing the relationship or interaction between organisms and their biotic and abiotic environment and how the consequences are caused. Second, focus on scientific ecology (a sub-discipline of biology). Third, relating to political issues and public policies and areas close to norms in society.

\section{Method}

The research method used is qualitative because the problems studied are social and dynamic problems. According to Sujarweni (2014), the primary purpose of qualitative research is to understand social phenomena or symptoms by explaining the form of a clear depiction of these social symptoms or symptoms in the way of a series of words that will ultimately produce a theory [7]. Qualitative research is research that aims to understand phenomena holistically and descriptively in the form of words and language in a specific natural context and by utilizing various scientific methods [8].

This study aims to see the growth pattern of the Pancur Batu sub-district in the Deli City Serdang district based on an ecological approach. The method used is qualitative. The research 
was conducted by saving the research location. In determining the location of the study, the site under investigation follows the formulation of the problem, namely the area of the Pancur Batu Subdistrict.

\section{Research Area}

The locations in the study are the Kecamatan Pancur Batu sub-district in Deli Serdang, Kabupaten Deli Serdang is a regency in the Indonesian province of North Sumatra (Figure 1). It surrounds the city of Medan and also borders the chartered city Binjai, which is effectively a bedroom community for Medan. It occupies an area of 2,497.72 sq .km (964.38 sq miles). The capital of the district is Lubuk Pakam, which is located approximately $30 \mathrm{~km}$ east of Medan. The national census of 2000 recorded 1,573,987 people, but by 2010 the regency's population increased by $13.76 \%$ to $1,790,431$, and at the 2015 Census, the total was 2,025,533; the latest official estimate (at mid-2018) is 2,155,625. Kualanamu International Airport is in this regency. [9]. Pancur Batu is a sub-district in Deli Serdang Regency, North Sumatra, Indonesia. Pancur Batu is the main road to Berastagi, Karo. In this sub-district, there are also several centres of the economic sector, one of which is the Pancur Batu Market [10].

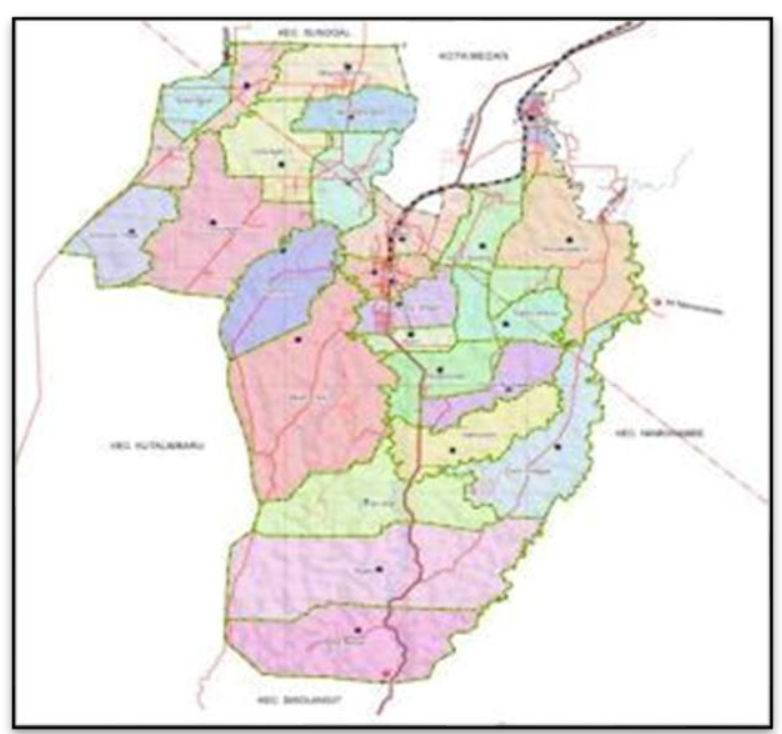

Figure 1 Sub - District of Pancur Batu 


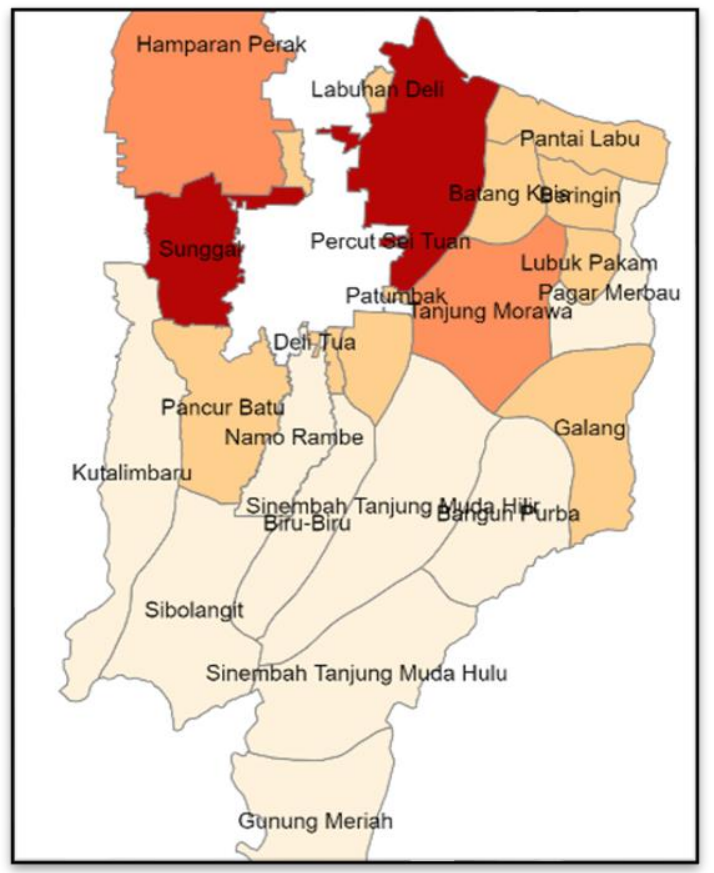

Figure 2 District division of Deli Serdang

The research location, which is located in the Pancur Batu sub-district, Deli Serdang regency, has administrative boundaries, which can be seen from the table below. Pancur Batu subdistrict, which is planned according to the RTRW of Deli Serdang district as a regional service centre area that will be developed for local trade and services (primary market and vegetable terminal), as well as studying TOD (transit-oriented development) and others. Administrative limits can be seen in Table 2.

Table 2 Administrative Restrictions of District Pancur Batu

\section{Administrative Restrictions}

North In the north, it is bordered by Medan Tuntung and Medan Sunggal Districts

South In the south, it is bordered by Sibolangit District

East In the east is the village of Namo Rambe

West In the west is bordered by Kutalimbaru District

\section{The growth pattern of Pancur Batu based on an ecological approach}

\subsection{Land Use of The Research Area}

The research area of Pancur Batu sub-district, which is an area that is administratively stipulated in the RTRW 2007-2027 [11], Pancur Batu sub-district which is the access to Berastagi, will also be developed into a regional service centre area which will be created for local trade and 
services (primary market and terminal vegetables), also studied TOD (transit Oriented Development) and others [12].

The results of the research were processed through satellite imagery in the last ten years to show changes in growth patterns in the rock-crushed area [13]. In general, the results of the existence of the Pancur Batu area are watersheds, forests, residential areas, vacant land, trade and services, dryland agriculture, green open space, agriculture, livestock, facilities and infrastructure, and shrubs. The growth in the last ten years has not shown the addition of new types, but on the contrary, the residential area has increased.

Pancur Batu has a total of 25 villages with an area of $122.53 \mathrm{Ha}$ [14]. The development of the Pancur Batu sub-district generally occurs in land use for built-up areas such as settlements, trade and services, and facilities and infrastructure that tend to increase the region by converting forest land uses.

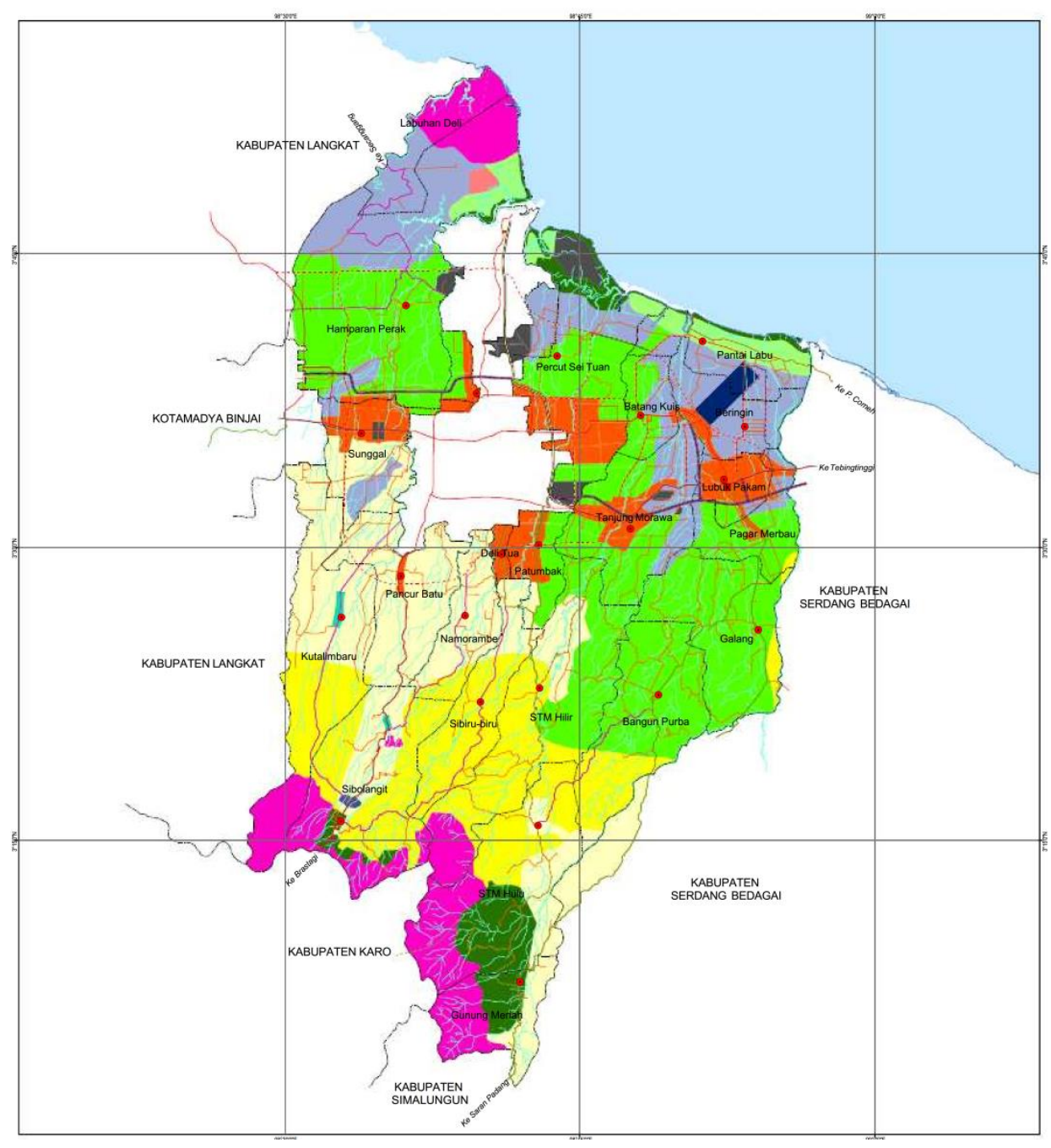

Figure 3 Map of the topography of Deli Serdang 


\subsection{Developmental Patterns of the research area}

The development pattern of the research area as a result of developments caused by several factors of population development is also accompanied by the action of functions of community activities, one of which is the establishment of a wholesale market around the Pancur Batu area, Pancur Batu which is the primary access coming and going to Karo land resulting in the existence of activities or movements that occur between research areas that are close to each other and interact with each other.

Then based on the regional development map, the direction of physical development in the area of the study area follows the service and trade centre areas connected to the road network. The physical propagation between the Pancur Batu sub-district and Medan city follows a network pattern and performs different propagations in every part of the Pancur Batu sub-district, which is called longitudinal or linear physical development.

According to Adisasmita (2006), the topographical division of villages is divided into four,[15] namely: mountainous areas, highland villages, lowland villages, and coastal (coastal) villages. The condition of the town has resulted in an elongated pattern of residential space structures (Linkage). Usually, a city with a flat topography has a tendency to have a long or linear physical village with a clustered (centralized) settlement development due to the existence of service centres such as economic activities, which can have the effect of making the surrounding settlements centralized and then developing outward as far as service centres. Villages with residential forms are scattered in all directions, this form of payment with several groups of houses separated by distances due to agricultural or plantation activities whose people tend to be agrarian to cultivate their land while building homes in that place.

\section{Conclusion}

The development pattern of Pancur Batu did not experience significant growth, while the most growth was residential areas. This development is not in line with the Deli Serdang regency government's plan to target the Pancur Batu sub-district as a regional trade and service centre because many products have occurred in residential areas. The road network and facilities and infrastructure are not much developed in this Pancur Batu sub-district. 


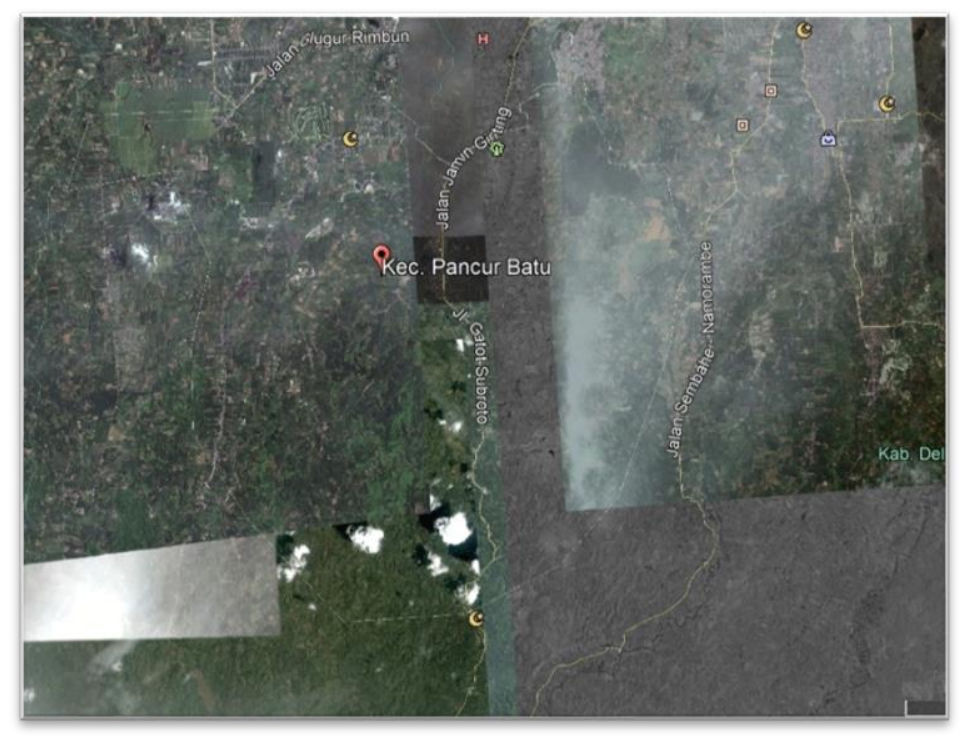

Figure 4 Map of Pancur Batu 2010

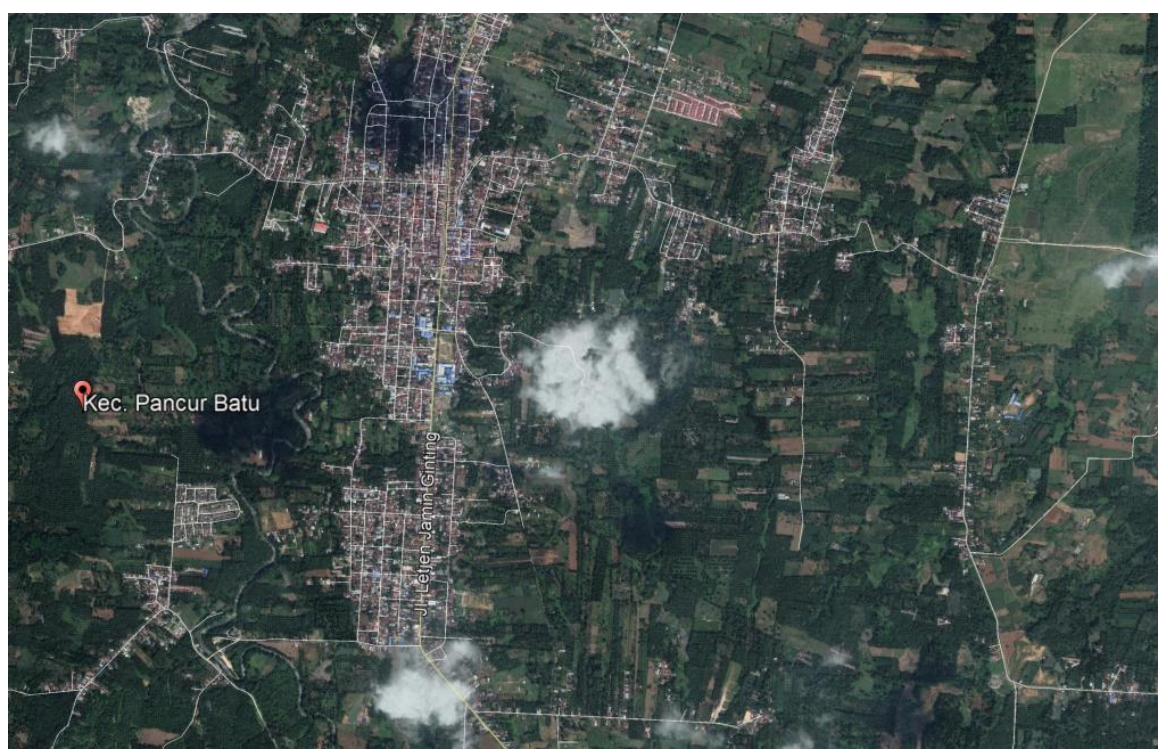

Figure 5 Map of Pancur Batu 2020

While several villages in Pancur Batu Subdistrict have almost no development, Pancur Batu itself has 25 villages. Several towns in the Pancur Batu sub-district have inadequate facilities and infrastructure, roads that are not feasible (severely damaged), which affects the development of an area. The trend in the structure of the sub-district development pattern is determined from the development of the road network; road development will affect several components forming an area and is followed by the growth of several new settlements, which will also create a new environmental centre. 


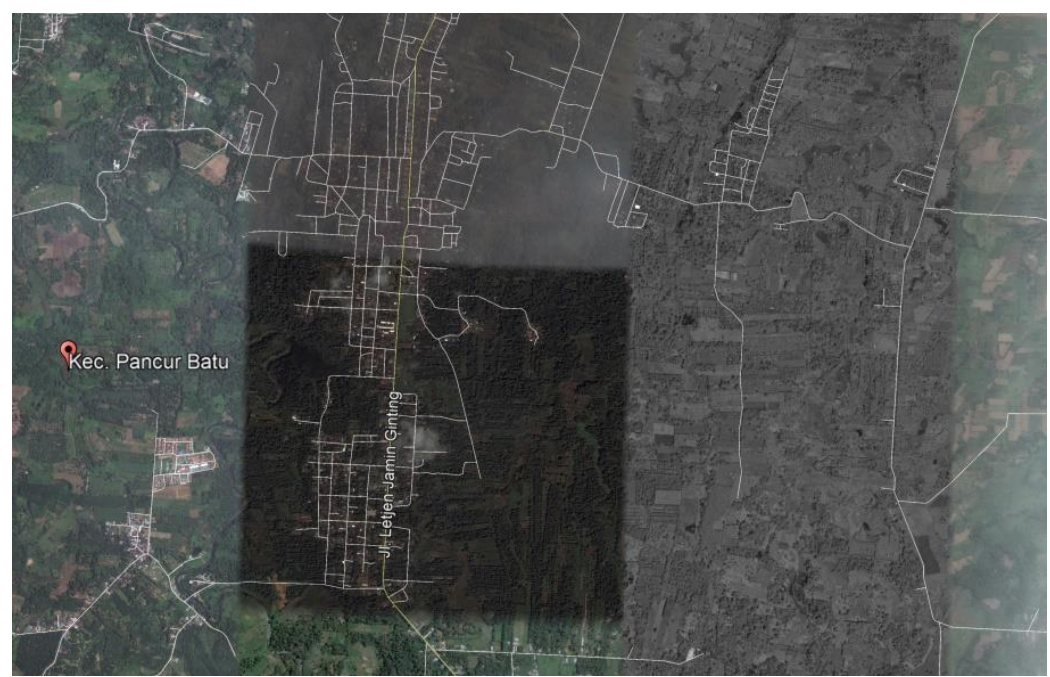

Figure 6 Map of Desa Namo Iram Pancur Batu 2010

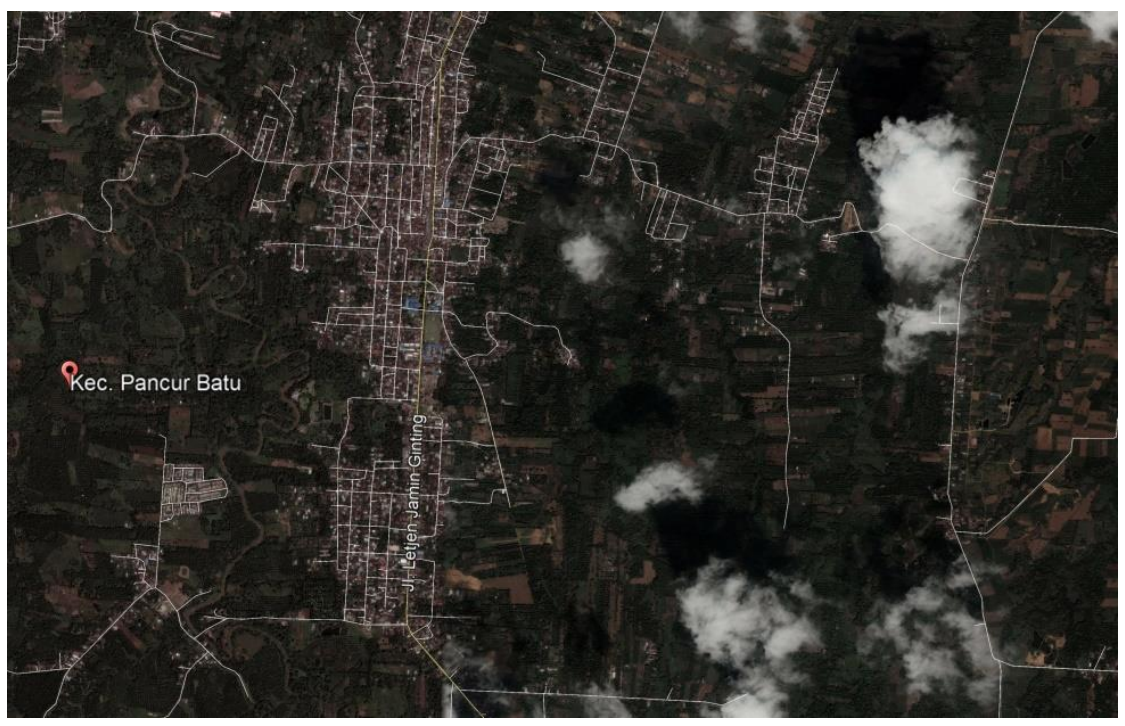

Figure 7 Map of Desa Namo Iram Pancur Batu 2015

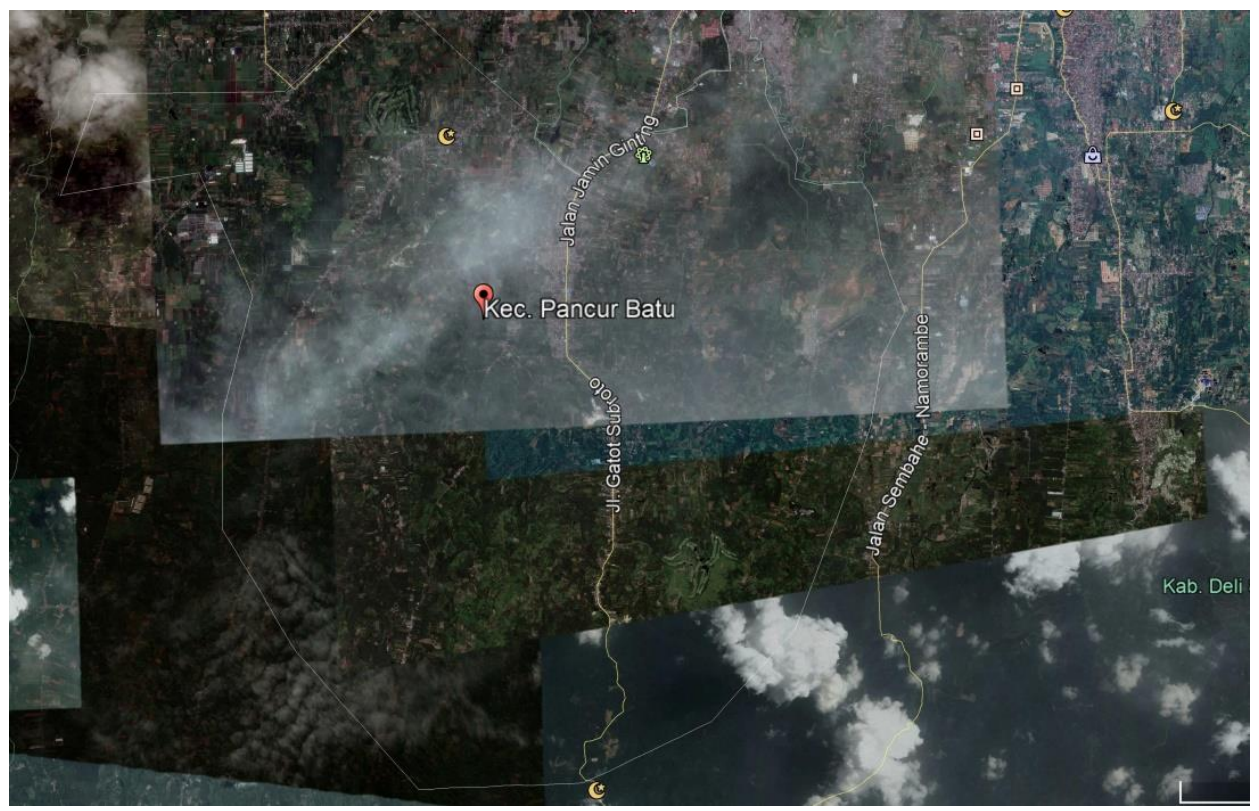

Figure 8 Map of Desa Namo Iram Pancur Batu 2020 
It can be seen from figures 6 to 8 that the changes in Pancur Batu sub-district, Deli Serdang district did not experience much change, the dominant change occurred in the panduduk area as happened in one of the villages in Pancur Batu sub-district.

\section{REFERENCES}

[1] Tallo, A. J., Pratiwi, Y., \& Astutik, I. (2014). Identifikasi Pola Morfologi Kota (Studi Kasus: Sebagian Kecamatan Klojen, Di Kota Malang). Jurnal Perencanaan Wilayah dan Kota, 25(3), 213-227.

[2] Badan Pusat Statistik, "Hasil sensus penduduk kabupaten Deli Serdang”2010.[Online] Available: $\quad$ https://sp2010.bps.go.id/index.php/site/tabel?tid=337\&wid=1212000000 [Accessed: Nov. 2, 2020].

[3] Sitepu, Beri Pana. "Kajian organologis kulcapi pada masyarakat Karo buatan Bapak Pauji Ginting." (2013). [Accessed: Nov. 2, 2020].

[4] Ministry of PU Cipta Karya" Dokumen profil Kabupeten Deli Serdang" [Online] Available:

http://sippa.ciptakarya.pu.go.id/sippa_online/ws_file/dokumen/rpi2jm/DOCRPIJM_1491 490433Bab_4_Profil_Kab_DSR.pdf [Accessed: Nov. 2, 2020].

[5] Worster, D., 1977. Nature's Economy: A History of Ecological Ideas.Cambridge: Cambridge University Press.

[6] Yunus, H.S. 2008. Konsep dan Pendekatan Geografi: Memaknai Hakekat Keilmuannya. Makalah disampaikan dalam Sarasehan Forum Pimpinan Pendidikan Tinggi Geografi Indonesia pada tanggal 18-19 Januari 2008 di Fakultas Geografi UGM Yogyakarta.

[7] Sujarweni, and V. Wiratna, Research Methodology. Jakartaa: Pustaka Baru Press, 2014.

[8] Moleong, and Lexy J., Qualitative Research Methodology (Revised Edition). Bandung: PT. Remaja Rosdakarya, 2014.

[9] "Deli Serdang" in Wikipedia, 2015. [Online]. Available: https://en.wikipedia.org/wiki/Deli_Serdang_Regency [Accessed: Nov. 3, 2020].

[10] "pancur batu" in Wikipedia, 2015. [Online]. Available: https://id.wikipedia.org/wiki/Pancur_bnhBatu,_Deli_Serdang [Accessed: Nov. 3, 2020].

[11] Bappeda Kabupaten Deli Serdang 2019, Rencana Tata Ruang dan Wilayah (RTRW) Kabupaten Deli Serdang, BAPPEDA kabupaten Deli Serdang.

[12] Bappeda Kabupaten Deli Serdang 2079, Bantuan Teknis RPI2JM kabupaten Deli Serdang 2015-2019 Dalam Implementasi kebijakan keterpaduan program bidang cipta karya Kabupaten Deli Serdang, BAPPEDA Kabupaten Deli Serdang.

[13] Tina, Tian. "THEORY, APPLICATION AND PROSPECT OF NEGATIVE PLANNING APPROACH." Landscape Architecture Frontiers 4.5 (2016): 18-30.

[14] Kecamatan Pancur Batu, profil kecamatan Pancur Batu 2020.[Online] Available : https://pancurbatu.deliserdangkab.go.id/ . [Accessed : Nov. 3,2020]

[15] Adisasmita R., 2006, "Pembangunan Pedesaan Dan Perkotaan”. Graha Ilmu. Yogyakarta 